\title{
Prevalence of nutritional deficiency in patients with pulmonary tuberculosis*
}

\author{
Prevalência de deficiência nutricional em pacientes com \\ tuberculose pulmonar*
}

\author{
Silvana Gomes Nunes Piva, Maria da Conceição Nascimento Costa, \\ Florisneide Rodrigues Barreto, Susan Martins Pereira
}

\begin{abstract}
Objective: To determine the prevalence of nutritional deficiency among patients with pulmonary tuberculosis. Methods: This was a cross-sectional study using data obtained from the Brazilian Case Registry Database and from the medical records of patients diagnosed with pulmonary tuberculosis (15-59 years of age) residing in one of the municipalities that make up the 16th Regional Health District of the state of Bahia. We calculated the incidence, lethality, and mortality rates, as well as the prevalence of nutritional deficiency, as evaluated by body mass index. Demographic, social, clinical, and epidemiological data were collected. Results: Of the 72 confirmed cases of tuberculosis, $59(81.9 \%)$ were in males, and $21(29.2 \%)$ of the patients were in the 40-49 year age bracket. The majority (85.3\%) described themselves as Mulatto or Black; 55.2\% reported using alcohol; and approximately $90 \%$ were treated as outpatients. In the district and age bracket studied, the incidence of pulmonary tuberculosis was 30.6/100,000 population. Among the 72 patients, data regarding nutritional status was available for 34 . Of those, $50 \%$ and $25 \%$, respectively, presented nutritional deficiency at the beginning and at the end of treatment. No statistically significant differences were found between normal-weight and malnourished patients regarding the characteristics studied. Conclusions: The prevalence of nutritional deficiency was high among our sample of patients with pulmonary tuberculosis. This underscores the importance of nutritional follow-up for the assessment of tuberculosis treatment in the decision-making process regarding therapeutic interventions.
\end{abstract}

Keywords: Malnutrition; Tuberculosis; Body mass index; Malnutrition/epidemiology.

\section{Resumo}

Objetivo: Determinar a prevalência de deficiência nutricional entre pacientes com tuberculose pulmonar. Métodos: Estudo transversal tendo como fontes de dados o Sistema de Informação de Agravos de Notificação e prontuários médicos de pacientes diagnosticados com tuberculose pulmonar (15-59 anos de idade) e residentes nos municípios da 16a Regional de Saúde do estado da Bahia. Foram calculados os coeficientes de incidência, letalidade e mortalidade por tuberculose e a prevalência de deficiência nutricional, avaliada pelo índice de massa corpórea. Características demográficas, sociais e clínico-epidemiológicas foram coletadas. Resultados: Dos 72 casos confirmados de tuberculose, 59 (81,9\%) eram do sexo masculino, e $21(29,2 \%)$ tinham 40-49 anos de idade. A maioria declarou-se como pardo ou preto $(85,3 \%)$. 0 tratamento foi ambulatorial em aproximadamente 90\% dos casos, e 55,2\% referiram uso de álcool. A incidência de tuberculose pulmonar foi de 30,6/100.000 habitantes no distrito e faixa etária estudados. Dos 72 pacientes, 34 apresentavam dados relativos ao estado nutricional. Desses, 50\% e 25\%, respectivamente, apresentavam deficiência nutricional ao início e ao final do tratamento. Não houve diferenças estatisticamente significantes entre pacientes eutróficos e desnutridos quanto às características estudadas. Conclusões: A prevalência de deficiência nutricional foi elevada em nossa amostra de pacientes com tuberculose pulmonar. Isso reforça a importância do acompanhamento nutricional para a avaliação do tratamento da tuberculose para a tomada de decisão quanto a intervenções terapêuticas. Descritores: Desnutrição; Tuberculose; Índice de massa corporal; Desnutrição/epidemiologia.

*Study carried out at the Collective Health Institute, Federal University of Bahia, Salvador, Brazil.

Correspondence to: Maria da Conceição Nascimento Costa. Rua Basílio da Gama, s/n, Canela, CEP 40110-040, Salvador, BA, Brasil. Tel. 5571 3283-7373. Fax: 5571 3293-7460.E-mail: mcncosta@ufba.br Financial support: None.

Submitted: 31 January 2013. Accepted, after review: 5 June 2013. 


\section{Introduction}

Tuberculosis, a disease that is considered neglected, affects large population groups, especially in developing countries, where it is of significant magnitude and social importance; therefore, it is a major public health problem. Approximately 95\% of the estimated number of tuberculosis cases occur in resource-poor countries, and $82 \%$ are concentrated in 22 of these countries, among which is Brazil, which ranks 17 th. $^{(1)}$

Estimates indicate that, in 2010, approximately 270,000 new cases of tuberculosis were in the Americas, ${ }^{(2)}$ which corresponds to an incidence rate of 28.9 per 100,000 population. Brazil, a country considered a priority in the fight against tuberculosis in the continent, was among those that reached the target detection rate set by the World Health Organization (WHO), since it identified $88 \%$ of new active cases. However, it achieved a cure rate of only $72 \%$, a value that is lower than the recommended target rate of 85\% for successful treatment. ${ }^{(1)}$ In 2011 in Brazil, 71,337 new cases of tuberculosis were reported, corresponding to an incidence of $37.1 / 100,000$ population, and 4,600 deaths from tuberculosis were registered. The states of Rio de Janeiro, Amazonas, Pernambuco, Pará, Rio Grande do Sul, São Paulo, Ceará, and Acre had values above the national average, whereas Tocantins $(14.1 / 100,000)$, Goiás $(13.6 / 100,000)$, and the Federal District of Brasília (11.1/100,000) have historically registered the lowest rates. ${ }^{(3)}$

In the state of Bahia, there has been a gradual decline in the incidence of tuberculosis. This indicator decreased by 29.6\%, from 51.0/100,000 to $35.9 / 100,000$ population, between 2003 and 2011. ${ }^{(3)}$ It is possible that improved living conditions and the increased effectiveness of the tuberculosis control program in this period contributed to this trend. Despite this decline, the disease rates remained equal to or greater than $30 / 100,000$ population in nearly $45 \%$ of the Regional Health Districts in 2009. In the 16th Regional Health District, the incidence was, on average, 25.3/100,000 population between 2004 and 2009, with the highest rates in the period (around 30.0/100,000) being registered in 2005, 2006, and 2009.(4)

The association between tuberculosis, malnutrition, and poverty is well established. However, this relationship is known to be bidirectional, because the clinical course of the disease leads to secondary malnutrition, and malnutrition is also a risk factor for the disease. (5) Depending on the severity and/or duration of nutritional imbalance, a patient's nutritional status can deteriorate. ${ }^{(6)}$ Another aspect that must also be considered is the interaction of drugs and nutrients. In the presence of nutrients, the drugs might not reach effective levels in the blood, their effects might be prolonged by their slow absorption, or they might cause nutrient depletion, leading to nutritional deficiencies. ${ }^{(7)}$ On the basis of this knowledge, the four drugs used for the treatment of tuberculosis (pyrazinamide, rifampin, isoniazid, and ethambutol) are administered orally, in a single daily dose before breakfast, to increase their absorption. ${ }^{(8)}$ Therefore, the importance of assessing the nutritional status of patients with tuberculosis is evident.

Investigations of the nutritional status of tuberculosis patients conducted in Brazil have shown varying results. An evaluation of 31 women with tuberculosis reported that $61.3 \%$ had protein-energy malnutrition, ${ }^{(5)}$ whereas another investigation found similar values (33.3\% and $31.3 \%$, respectively) for the prevalence of underweight among men and women. ${ }^{(9)}$

The objective of the present study was to determine the prevalence of nutritional deficiency in patients with pulmonary tuberculosis in order to produce information that can help ensure quality follow-up care for patients being treated for this disease, as well as their recovery.

\section{Methods}

This was a cross-sectional descriptive study using data obtained from the Brazilian Case Registry Database of the 16th Regional Health District of the state of Bahia and from the medical records of patients in whom the diagnosis of pulmonary tuberculosis had been confirmed, in accordance with the recommendation of the Brazilian National Ministry of Health. ${ }^{(10)}$ This Regional Health District, the headquarters of which are in the municipality of Jacobina, includes 19 municipalities that comprise the Chapada Norte (Northern Plateau) of the state and has 377,710 inhabitants. ${ }^{(11)}$ All of the 159 primary health care clinics, as well as $93.5 \%$ of the 957 hospital beds, are part of the Brazilian Unified Health Care System, which employs more than $90 \%$ of the health professionals in the region. 
The study population consisted of individuals, aged 15-59 years, residing in one of the municipalities that make up the 16th Regional Health District. We considered all of the reported cases of tuberculosis for which, upon the diagnosis being confirmed, initiated treatment in April of 2008 and completed it by March of 2009. Elderly individuals were not included because, in general, they exhibit aging-related characteristics, such as progressive decrease in height and progressive increase in weight and body mass index (BMI) up to 65-70 years of age, from which point on the body composition changes are reduced. ${ }^{(12)}$

The collected data was recorded on a form with closed questions related to the variables, such as age, gender, height, weight at treatment initiation, weight over the six months of treatment, etc. We calculated the incidence rate of confirmed cases of tuberculosis and the prevalence of nutritional deficiency among these patients for the regional district as a whole and for each of its municipalities. Nutritional deficiency was defined a BMl $<18.5 \mathrm{~kg} / \mathrm{m}^{2}{ }^{(13)}$ and, for the calculation of this indicator, only consistent and complete information was considered. We analyzed the frequency distribution of the demographic, social, clinical, and epidemiological characteristics of the patients and conducted statistical testing of differences between proportions. The level of significance was set at 0.05 . We calculated tuberculosis mortality and lethality rates for the regional district.

The study project was approved by the Research Ethics Committee of the Collective Health Institute of the Federal University of Bahia (CEP/ISC no. 47/2010).

\section{Results}

In 4 of the 19 municipalities that make up the 16th Regional Health District, no confirmed cases of pulmonary tuberculosis were reported during the study period. In the remaining municipalities, 102 cases were reported, of which 72 were confirmed. Of those 72 , most $(81.9 \%)$ were in males, and most of the patients (57.0\%) were in the 30-49 year age bracket (Table 1). The mean age was $39.8 \pm 10.8$ years for the sample as a whole, 40.8 \pm 10.7 years for males, and $34.2 \pm 9.8$ years for females. Of the total number of patients, $75.5 \%$ had had up to four years of schooling, 64.7\% were Mulatto, and 20.6\% were Black.
Table 2 shows that $77.8 \%$ of the confirmed cases were admitted to tuberculosis facilities as new cases, and that $90.7 \%$ of the patients were treated as outpatients. Transfer to other facilities and recurrence accounted for $12.5 \%$ and $8.3 \%$ of the cases, respectively. Smear microscopy/first sample was positive in $70.8 \%$ of the cases, and $5.6 \%$ patients did not undergo the test. Data regarding smear microscopy/second sample was available for 54 patients, of whom 22.2\% did not undergo the test and $61.1 \%$ had a positive result. Comorbidities were reported in 29 cases (40.3\%). Of those patients, 55.2\% reported using alcohol and $24.1 \%$ reported having diabetes. Testing for HIV was performed in $44.4 \%$ of the cases, and, for the remaining cases, no data regarding HIV testing results was available by treatment completion. At 9 months of follow-up, when the case is considered closed, $75.0 \%$ of the patients were cured, 5.6\% had been noncompliant with the treatment, and $2.8 \%$ had died from tuberculosis. For 6.8\%, no outcome data was available. Malnourished and normal-weight patients differed in terms of the frequency of transfer (15.4\% vs. 0.0\%), positive smear microscopy/ first sample (69.2\% vs. 61.9\%), positive smear microscopy/second sample (77.8\% vs. $46.7 \%$ ), and treatment noncompliance (15.4\% vs. 9.4\%). Although there were no statistically significant differences between malnourished and normalweight patients regarding alcohol consumption (50.0\% vs. $66.7 \%)$ or cure $(76.9 \%$ vs. $81.0 \%)$, the latter had higher rates.

Table 1- Confirmed new cases of pulmonary tuberculosis in patients between 15 and 59 years of age by gender and age bracket between April of 2008 and March of 2009 in the 16th Regional Health District of the state of Bahia.

\begin{tabular}{|c|c|c|c|c|c|c|}
\hline \multirow{3}{*}{$\begin{array}{l}\text { Age bracket, } \\
\text { years }\end{array}$} & \multicolumn{4}{|c|}{ Gender } & \multicolumn{2}{|c|}{ Total } \\
\hline & \multicolumn{2}{|c|}{ Male } & \multicolumn{2}{|c|}{ Female } & & \\
\hline & $n$ & $\%$ & $n$ & $\%$ & $n$ & $\%$ \\
\hline $15-19$ & 2 & 3.4 & 1 & 7.7 & 3 & 4.2 \\
\hline $20-29$ & 7 & 11.9 & 3 & 23.1 & 10 & 13.9 \\
\hline 30-39 & 14 & 23.7 & 6 & 46.2 & 20 & 27.8 \\
\hline $40-49$ & 19 & 32.2 & 2 & 15.4 & 21 & 29.2 \\
\hline $50+$ & 17 & 28.8 & 1 & 7.7 & 18 & 25.0 \\
\hline Total & 59 & 81.9 & 13 & 18.1 & 72 & 100.0 \\
\hline
\end{tabular}

Source: Sistema de Informação de Agravos de Notificação (SINAN, Brazilian Case Registry Database) - $16^{a}$ Diretoria

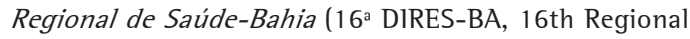
Health Board of the state of Bahia). 
Table 2 - Confirmed new cases of pulmonary tuberculosis in patients between 15 and 59 years of age by selected characteristics and nutritional status between April of 2008 and March of 2009 in the 16th Regional Health District of the state of Bahia. ${ }^{\mathrm{a}}$

\begin{tabular}{|c|c|c|c|}
\hline \multirow[t]{2}{*}{ Characteristic } & \multicolumn{2}{|c|}{ Nutritional status* } & \multirow[t]{2}{*}{ Total } \\
\hline & Normal-weight & Malnourished & \\
\hline Type of admission & $(\mathrm{n}=21)$ & $(n=13)$ & $(n=72)$ \\
\hline New case & $15(71.4)$ & $10(76.9)$ & $56(77.8)$ \\
\hline Transfer & ND & $2(15.4)$ & $9(12.5)$ \\
\hline Recurrence & $5(23.8)$ & $1(7.7)$ & $6(8.3)$ \\
\hline Readmission for noncompliance & $1(4.8)$ & ND & $1(1.4)$ \\
\hline Institutionalization & $(\mathrm{n}=16)$ & $(n=13)$ & $(n=54)$ \\
\hline Non-institutionalized & $14(87.5)$ & $12(92.3)$ & $49(70.7)$ \\
\hline Prison & ND & ND & $1(1.9)$ \\
\hline Others & $2(12.5)$ & $1(7.7)$ & $4(7.4)$ \\
\hline Diagnostic smear microscopy: 1st sample & $(\mathrm{n}=21)$ & $(n=13)$ & $(\mathrm{n}=72)$ \\
\hline Positive & $13(61.9)$ & $9(69.2)$ & $51(90.7)$ \\
\hline Negative & $7(33.3)$ & $4(30.8)$ & $17(23.6)$ \\
\hline Not performed & $1(4.8)$ & ND & $4(5.6)$ \\
\hline Diagnostic smear microscopy: 2nd sample & $(n=15)$ & $(n=9)$ & $(\mathrm{n}=54)$ \\
\hline Positive & $7(46.7)$ & 7 (77.8) & $33(61.1)$ \\
\hline Negative & $3(20.0)$ & $1(11.1)$ & $9(16.7)$ \\
\hline Not performed & $5(33.3)$ & $1(11.1)$ & $12(22.2)$ \\
\hline Comorbidities & $(n=6)$ & $(n=6)$ & $(n=29)$ \\
\hline Alcoholism & $4(66.7)$ & $3(50.0)$ & $16(55.2)$ \\
\hline Diabetes & $2(33.3)$ & $2(33.3)$ & $7(24.1)$ \\
\hline Mental illness & ND & $1(16.7)$ & $1(3.4)$ \\
\hline Others (smoking, lung tumor, etc.) & ND & ND & $5(17.2)$ \\
\hline HIV serology & $(\mathrm{n}=21)$ & $(\mathrm{n}=13)$ & $(n=63)$ \\
\hline Positive & ND & ND & ND \\
\hline Negative & $13(61.9)$ & $7(53.8)$ & $28(44.4)$ \\
\hline In progress & $8(38.1)$ & $6(46.2)$ & $35(55.6)$ \\
\hline Status at 9 months & $(\mathrm{n}=21)$ & $(\mathrm{n}=13)$ & $(n=72)$ \\
\hline Cure & $17(81.0)$ & $10(76.9)$ & $54(75.0)$ \\
\hline Noncompliance & $2(9.4)$ & $2(15.4)$ & $4(5.6)$ \\
\hline Death from tuberculosis & ND & ND & $2(2.8)$ \\
\hline Death from other causes & ND & ND & $1(1.4)$ \\
\hline Transfer within the same city & ND & ND & $2(2.8)$ \\
\hline Transfer to another city & ND & ND & $1(1.4)$ \\
\hline Transfer to another state & ND & ND & $1(1.4)$ \\
\hline Change in regimen because of drug intolerance & ND & ND & $1(1.4)$ \\
\hline Is still under treatment & $1(4.8)$ & ND & $1(1.4)$ \\
\hline No data & $1(4.8)$ & ND & $5(6.8)$ \\
\hline
\end{tabular}

Source: Sistema de Informação de Agravos de Notificação (SINAN, Brazilian Case Registry Database) - $16^{a}$ Diretoria Regional de Saúde-Bahia (16a DIRES-BA, 16th Regional Health Board of the state of Bahia). ND: no data aValues expressed as $n(\%)$. * No statistically significant differences were found between malnourished and normal-weight individuals regarding the variables studied. 
Table 3 - Confirmed new cases of pulmonary tuberculosis in patients between 15 and 59 years of age by nutritional status and results of follow-up smear microscopy during treatment between April of 2008 and March of 2009 in the 16th Regional Health District of the state of Bahia. ${ }^{a}$

\begin{tabular}{lccc}
\hline Smear microscopy results $^{\mathrm{b}}$ & \multicolumn{2}{c}{ Nutritional status* $^{*}$} & \multirow{2}{*}{ Total } \\
\cline { 2 - 3 } & Normal-weight & Malnourished & \\
\hline At 2 months & $(\mathrm{n}=18)$ & $(\mathrm{n}=12)$ & $(\mathrm{n}=62)$ \\
Positive & $1(5.6)$ & $1(8.3)$ & $6(9.7)$ \\
Negative & $13(72.2)$ & $8(66.7)$ & $37(59.7)$ \\
$\quad$ Not performed & $4(22.2)$ & $3(25.0)$ & $19(30.6)$ \\
At 4 months & $(\mathrm{n}=17)$ & $(\mathrm{n}=11)$ & $(\mathrm{n}=53)$ \\
Positive & $\mathrm{ND}$ & $\mathrm{ND}$ & $1(1.8)$ \\
Negative & $11(64.8)$ & $7(63.6)$ & $26(49.1)$ \\
Not performed & $6(35.2)$ & $4(36.4)$ & $26(49.1)$ \\
At 6 months & $(\mathrm{n}=16)$ & $(\mathrm{n}=11)$ & $(\mathrm{n}=57)$ \\
Positive & $\mathrm{ND}$ & $\mathrm{ND}$ & $2(3.5)$ \\
Negative & $14(87.5)$ & $8(72.7)$ & $46(80.7)$ \\
Not performed & $2(12.5)$ & $3(27.3)$ & $9(15.8)$ \\
\hline
\end{tabular}

Source: Sistema de Informação de Agravos de Notificação (SINAN, Brazilian Case Registry Database) - 16a Diretoria Regional de Saúde-Bahia (16a DIRES-BA, 16th Regional Health Board of the state of Bahia). ND: no data. ${ }^{\text {a }}$ Values expressed as $n$ $(\%)$. ${ }^{b}$ There were no records of results of follow-up smear microscopy at 2, 4, and 6 months, respectively, for 10 (14.0\%), $19(26.4 \%)$, and $15(20.8 \%)$ of the patients. *No statistically significant differences were found between malnourished and normal-weight individuals regarding the variables studied.

Table 4 - Incidence rate of pulmonary tuberculosis (per 100,000 population) and prevalence of malnutrition in patients between 15 and 59 years of age by municipality of residence, from baseline to the sixth month of treatment, in the 16th Regional Health District of the state of Bahia.

\begin{tabular}{lcccccccc}
\hline Municipality & $\begin{array}{c}\text { Incidence } \\
\text { rate }\end{array}$ & \multicolumn{7}{c}{ Prevalence of malnutrition by month of treatment } \\
\cline { 3 - 8 } & 34,0 & Baseline & 1 & 2 & 3 & 4 & 5 & 6 \\
\hline Caem & ND & ND & ND & ND & ND & ND & ND \\
Caldeirão Grande & 89.3 & $2(33.3)$ & $2(33.3)$ & $2(33.3)$ & $2(33.3)$ & $2(33.3)$ & $1(16.7)$ & $1(16.7)$ \\
Capim Grosso & 123.3 & $\mathrm{ND}$ & $3(0)$ & $1(0)$ & $2(0)$ & $2(0)$ & $3(0)$ & $0(0)$ \\
Jacobina & 40.6 & $2(28.6)$ & $3(42.8)$ & $2(50.0)$ & $4(50.0)$ & $2(33.3)$ & $2(33.3)$ & $1(16.7)$ \\
Mairi & 8.7 & $\mathrm{ND}$ & $\mathrm{ND}$ & $\mathrm{ND}$ & $\mathrm{ND}$ & $\mathrm{ND}$ & $\mathrm{ND}$ & $\mathrm{ND}$ \\
Miguel Calmon & 17.8 & $\mathrm{ND}$ & $\mathrm{ND}$ & $1(100)$ & $1(100)$ & $1(100)$ & $1(100)$ & $1(100)$ \\
Mirangaba & 9.3 & $\mathrm{ND}$ & $1(0)$ & $\mathrm{ND}$ & $1(0)$ & $1(0)$ & $\mathrm{ND}$ & $0(0)$ \\
Morro do Chapéu & 14.8 & $\mathrm{ND}$ & $1(33.3)$ & $1(33.3)$ & $1(33.3)$ & $3(0.0)$ & $2(0.0)$ & $0(0.0)$ \\
Ourolândia & 29.1 & $3(100.0)$ & $3(100.0)$ & $2(66.7)$ & $1(33.3)$ & $2(66.7)$ & $1(33.3)$ & $2(66.7)$ \\
Saúde & 13.6 & $1(100)$ & $1(100)$ & $\mathrm{ND}$ & $\mathrm{ND}$ & $\mathrm{ND}$ & $\mathrm{ND}$ & $\mathrm{ND}$ \\
Serrolândia & 25.9 & $1(100)$ & $\mathrm{ND}$ & $1(0)$ & $1(50)$ & $1(0)$ & $1(0)$ & $1(50)$ \\
Umburanas & 19.5 & $\mathrm{ND}$ & $1(0)$ & $1(0)$ & $1(0)$ & $1(0)$ & $1(0)$ & $0(0)$ \\
Várzea da Roça & 22.4 & $\mathrm{ND}$ & $\mathrm{ND}$ & $\mathrm{ND}$ & $\mathrm{ND}$ & $\mathrm{ND}$ & $\mathrm{ND}$ & $\mathrm{ND}$ \\
Várzea do Poço & 18.1 & $\mathrm{ND}$ & $\mathrm{ND}$ & $\mathrm{ND}$ & $\mathrm{ND}$ & $\mathrm{ND}$ & $\mathrm{ND}$ & $\mathrm{ND}$ \\
Várzea Nova & 11.5 & $\mathrm{ND}$ & $\mathrm{ND}$ & $\mathrm{ND}$ & $\mathrm{ND}$ & $\mathrm{ND}$ & $\mathrm{ND}$ & $\mathrm{ND}$ \\
TOTAL & 30.6 & $9(50.0)$ & $15(60.0)$ & $11(55.0)$ & $14(60.9)$ & $15(62.5)$ & $12(52.1)$ & $6(50.0)$ \\
\hline
\end{tabular}

Source: Sistema de Informação de Agravos de Notificação (SINAN, Brazilian Case Registry Database) - 16a Diretoria Regional

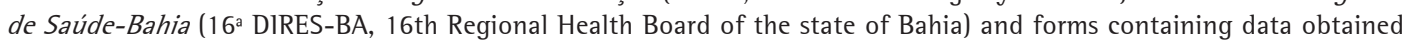
from the medical records of patients residing in one of the 15 municipalities. ND: no data. ${ }^{a}$ Values expressed as $n(\%)$. 
At 2 months, 59.7\% and 30.6\% of the 62 patients for whom data regarding follow-up smear microscopy during treatment were available had negative results and did not undergo the test, respectively (Table 3). At 4 months of treatment, $1.8 \%, 49.1 \%$, and $49.1 \%$ of the 53 patients for whom these data were available had positive results, had negative results, and did not undergo the test, respectively. At 6 months, 3.5\%, 80.7\%, and $15.8 \%$ of the 57 patients for whom these data were available had positive results, had negative results, and did not undergo the test, respectively. The greatest differences between malnourished and normal-weight patients were found in the proportion of positive smear microscopy (8.3\% vs. 5.6\%) and negative smear microscopy (72.7\% vs. $87.5 \%$ ) at 2 months. Although there were no records of positive smear microscopy at 4 or 6 months of treatment, the proportion of patients who did not undergo the test was high in the two groups. The differences found were not statistically significant.

The incidence of pulmonary tuberculosis for the 16th Regional Health District was $30.6 / 100,000$ population aged $15-59$ years. In the municipalities of Caldeirão Grande, Capim Grosso, and Jacobina, the value of this indicator (per 100,000 population) was $89.3,123.3$, and 40.6, respectively, whereas in the municipalities of Mairi and Mirangaba, the incidence rate was lowest (8.7 and 9.3, respectively). The prevalence of malnutrition among the cases of pulmonary tuberculosis was $50.0 \%$ at treatment initiation, $60.0 \%$ at 1 month of follow-up, and 50.0\% at 6 months of follow-up. At these same time points, the BMl means were $17.7 \pm 3.2 \mathrm{~kg} / \mathrm{m}^{2}, 17.3 \pm 3.4$ $\mathrm{kg} / \mathrm{m}^{2}$, and $21.0 \pm 3.3 \mathrm{~kg} / \mathrm{m}^{2}$, respectively, among the cases for which data regarding weight and height were available. In $10(66.7 \%)$ of the 15 municipalities in which cases were reported, data regarding these two variables were available for at least a treatment month. Throughout the period analyzed, variation in BM1 occurred in only 29 cases. The prevalence of nutritional deficiency at baseline was 33.3\% in Caldeirão Grande; 28.6\% in Jacobina; and 100\% in Ourolândia, Saúde, and Serrolândia (Table 4).

During the study period, lethality from pulmonary tuberculosis was $3 \%$, whereas the mortality rate was $0.84 / 100,000$ population. No deaths from tuberculosis occurred among malnourished patients.

\section{Discussion}

The findings of the present study are suggestive of the existence of a high prevalence $(50 \%)$ of malnutrition among patients with pulmonary tuberculosis in the 16th Regional Health District, this prevalence being even higher than that found in Rio de Janeiro (32\%) $)^{(9)}$ and São Paulo (34.9\%). ${ }^{(14)}$ This problem has also been found to be very common in hospitalized patients with tuberculosis in São Paulo and northeastern Brazil. ${ }^{15,16)}$ Likewise, underweight was present in 49\% of 49 indigenous subjects under 15 years of age diagnosed with tuberculosis in Mato Grosso do Sul between 2007 and 2010. ${ }^{(17)}$

Although, perhaps because of the small numbers, no statistically significant differences were found between malnourished and normal-weight patients regarding the characteristics analyzed, the rate of treatment noncompliance (15.4\%), almost twice as high among malnourished patients, is of note, exceeding 5\%, the value considered acceptable. ${ }^{(18)}$ This may be related to the higher frequency of side effects of chemotherapy among patients with this condition, ${ }^{(19)}$ especially gastric intolerance, because it complicates the continuity of treatment. In fact, the nutritional status of patients is reported as one of the factors that may be related to the side effects of tuberculosis treatment ${ }^{(20)}$ and as a reason for noncompliance, ${ }^{(21)}$ i.e., contributing to nonadherence to treatment. In addition, malnourished patients have alterations in immune mechanisms, ${ }^{(22)}$ and this is a possible hypothesis to explain the higher frequency of positive smear microscopy among these patients.

In 2009, the incidence of pulmonary tuberculosis (30.6/100,000 population) in the population of the regional health district investigated was lower than that found in Salvador $(58.9 / 100,000)$, the capital of the state of Bahia, for that same year, ${ }^{(23)}$ which may be a result of the possible occurrence of greater underreporting of tuberculosis in the interior of this state. The predominance of the disease in males and adults is consistent with the literature, ${ }^{(24,25)}$ as is the lower level of education ${ }^{(26)}$ and the predominance of cases among Mulattos and Blacks. ${ }^{(27)}$ In addition, alcohol consumption was very common among patients with tuberculosis, which is similar to results reported by other authors. ${ }^{(28,29)}$ Factors related to lifestyle and habits, as well as to socioeconomic and cultural conditions, are offered as possible explanations. The noncompliance 
rate (5.6\%) found for the group of patients with pulmonary tuberculosis in this regional district was close to the value considered acceptable, which represents a positive result. However, the cure rate $(75 \%)$ is slightly below the $85 \%$ rate set by the $\mathrm{WHO},{ }^{(1)}$ indicating the existence of a deficiency that needs to be identified and resolved.

We emphasize that, because the present study was based on secondary data that may present problems related to its scope and quality, our findings should be interpreted with caution. It is possible that limitations, such as underreporting of tuberculosis cases and incorrect and/or incomplete entries in some fields on the forms for data collection by health care facilities, affected the results presented. In the municipality of Belford Roxo, located in the state of Rio de Janeiro, a study on the quality of data regarding tuberculosis found a $6.4 \%$ underreporting rate in the triennium 2006-2008. ${ }^{(30)}$

We understand that the reduced number of tuberculosis cases for which data regarding weight and height were available is the major limitation of this investigation, making it impossible to obtain conclusive information about the true prevalence of malnutrition among patients. There is no doubt that underreporting of these data is a cause for concern, both because it is suggestive of the poor quality of health care provided and because of the importance of nutritional assessment for the analysis of treatment of this mycobacterial disease in the decision-making process regarding therapeutic interventions aimed at these patients. ${ }^{(6)}$

In view of the possibility that there is a high prevalence of nutritional deficiency among patients with pulmonary tuberculosis, and considering similar findings reported by other studies conducted in Brazil, we suggest that a specific field for recording weight, height, and BMl be added to the Follow-up Report Form of tuberculosis cases.

\section{References}

1. World Health Organization [homepage on the Internet]. Geneva: World Health Organization. [cited 2013 Jan 29]. Global tuberculosis report 2012. [Adobe Acrobat document, 98p.]. Available from: http://www.who.int/ tb/publications/global_report/gtbr12_main.pdf

2. Pan American Health Organization [homepage on the Internet]. Washington, D.C: Pan American Health Organization. [cited 2013 Sep 26]. World TB Day, 24 March 2012: "Stop TB in my lifetime". Available from: http://new.paho.org/hq/index.php?option=com_conten tctask=viewEtid=6529\&ltemid=3511 \&lang $=e n$
3. Portal da Saúde [homepage on the Internet]. Brasília: Ministério da Saúde. [cited 2012 Dec 28]. Boletim Epidemiológico. Especial Tuberculose. Volume 43 março, 2012. [Adobe Acrobat document, 12p.]. Available from: http://portal.saude.gov.br/portal/arquivos/pdf/ bolepi_v43_especial_tb_correto.pdf

4. Secretaria da Saúde do Estado da Bahia [homepage on the Internet]. Salvador: Secretaria da Saúde do Estado da Bahia. [cited 2012 Nov 15]. Casos de Tuberculose confirmados e notificados no SinanNET - Bahia. Available from: http://www3.saude.ba.gov.br/cgi/deftohtm. exe?tabnet/sinan/tube.def

5. Nogueira CR, Chaves GV, Teixeira MT, Franca CA, Ramalho R. Aspectos antropométricos, bioquímicos e sintomatológicos em mulheres com tuberculose pulmonar. Rev Cienc Med Campinas. 2006;15(4):281-8.

6. Vannucchi H, Unamuno MR, Marchini JS. Avaliação do estado nutricional. Medicina (Rib Preto). 1996;29(1):5-18.

7. Cuppari L, organizer. Guias de Medicina Ambulatorial e Hospitalar UNIFESP/EPM - Nutrição Clínica no Adulto. São Paulo: Editora Manole; 2002.

8. Portal da Saúde [homepage on the Internet]. Brasília: Ministério da Saúde. [cited 2010 Aug 10]. Tratamento diretamente observado (TDO) da tuberculose na atenção básica: protocolo de enfermagem. [Adobe Acrobat document, 168p.]. Available from: http://portal.saude. gov.br/portal/arquivos/pdf/manual_tdo_tb.pdf

9. Ramalho RA, Costa RS da, Vieira AC, Silva LB da, Machado FC, Menezes EM, et al. Avaliação nutricional de pacientes com tuberculose pulmonar atendidos na UISHL. Bol Pneumol Sanit. 2000;8(2):13-20.

10. Portal da Saúde [homepage on the Internet]. Brasília: Ministério da Saúde. [cited 2012 Sep 05]. Vigilância em Saúde: Dengue, Esquistossomose, Hanseníase, Malária, Tracoma e Tuberculose. Available from: http://portal. saude.gov.br/portal/arquivos/pdf/abcad21.pdf

11. Portal da Saúde [homepage on the Internet]. Brasília: Ministério da Saúde. [cited 2010 Sep 08]. Análise da disponibilidade domiciliar de alimentos e do estado nutricional no Brasil. Rio de Janeiro. Available from: http://www.ibge.gov.br/home/estatistica/populacao/ condicaodevida/pof/2002analise/default.shtm

12. Acu-a K, Cruz T. Avaliação do estado nutricional de adultos e idosos e situação nutricional da população brasileira. Arq Bras Endocrinol Metab. 2004;48(3):345-61. http://dx.doi.org/10.1590/S0004-27302004000300004

13. World Health Organization [homepage on the Internet]. Geneva: World Health Organization. [cited 2010 Aug 08]. Physical Status: The Use and Interpretation of Anthropometry - Report of a WHO Expert Committee. Available from: http://helid.digicollection.org/en/d/ Jh0211e/1.html\#Jh0211e.1

14. Souza AL, Ribeiro AS, Tudisco ES. Avaliação nutricional de pacientes tuberculosos em tratamento ambulatorial. J Pneumol. 1992;18(4):167-70.

15. Nogueira PA. Motivos e tempo de internação e o tipo de saída em hospitais de tuberculose do Estado de São Paulo, Brasil - 1981 a 1995. J Pneumol. 2001;27(3):123-9. http://dx.doi.org/10.1590/S0102-35862001000300001

16. Pinheiro VG, Barroso EC, Ramos LA, Monteiro HS, Lima $\mathrm{AM}$, Cordeiro Jl, et al. Estado nutricional de pacientes com tuberculose pulmonar hospitalizados no Nordeste do Brasil. J Pneumol. 2002;28(Suppl 2): 645.

17. dos Santos SC, Marques AM, de Oliveira RL, da Cunha RV. Scoring system for the diagnosis of tuberculosis in 
indigenous children and adolescents under 15 years of age in the state of Mato Grosso do Sul, Brazil. J Bras Pneumol. 2013;39(1):84-91. PMid:23503490

18. Brasil. Ministério da Saúde. Secretaria de Vigilância em Saúde. Departamento de Vigilância Epidemiológica. Manual de recomendações para o controle da tuberculose no Brasil. Brasília: Ministério da Saúde; 2011.

19. Brólio R. Quimioterapia da tuberculose. Rev Saude Publ. 1975;9(1):71-85. http://dx.doi.org/10.1590/ S0034-89101975000100011

20. Brasil. Ministério da Saúde. Fundação Nacional de Saúde. Centro de Referência Prof. Hélio Fraga. Sociedade Brasileira de Pneumologia e Tisiologia. Controle da tuberculose: uma proposta de integração ensino-serviço. Rio de Janeiro: FUNASA/CRPHF/SBPT; 2002.

21. Mendes AM, Fensterseifer LM. Tuberculose: porque os pacientes abandonam o tratamento? Bol Pneumol Sanit. 2004;12(1):27-38.

22. Alam 1, Larbi A, Pawelec G. Nutritional status influences peripheral immune cell phenotypes in healthy men in rural Pakistan. Immun Ageing. 2012;9(1):16. http:// dx.doi.org/10.1186/1742-4933-9-16 PMid:22863368 PMCid:3488561

23. Secretaria de Saúde do Estado da Bahia [homepage on the Internet]. Salvador: Secretaria de Saúde do Estado da Bahia. [cited 2012 Sep 19]. Diretoria de Informações em Saúde 2009. Available from: http://www.saude.ba.gov. br/cgi/tabcgi.exe?.tabnet/sinan/tube.def

24. Silveira MP, de Adorno RF, Fontana T. Profile of patients with tuberculosis: evaluation of the Brazilian national tuberculosis control program in Bagé, Brazil. J Bras
Pneumol. 2007;33(2):199-205. http://dx.doi.org/10.1590/ S1806-37132007000200015 PMid:17724540

25. Mendes JM, Fonseca Lde S, Lourenço MC, Ferreira RM, Saad MH. A retrospective study of the epidemiological aspects of tuberculosis in the Complexo de Manguinhos, an urban slum area in Rio de Janeiro, Brazil, 20002002. J Bras Pneumol. 2007;33(4):443-7. http://dx.doi. org/10.1590/S1806-37132007000400014 PMid:17982537

26. Maciel EL, Guidoni LM, Favero JL, Hadad DJ, Molino LP, Jonhson JL, et al. Adverse effects of the new tuberculosis treatment regimen recommended by the Brazilian Ministry of Health. J Bras Pneumol. 2010;36(2):232-8. PMid:20485945

27. de Oliveira HB, Moreira Filho Dde C. Tuberculosis recurrence and its risk factors [Article in Portuguese]. Rev Panam Salud Publica. 2000;7(4):232-41. PMid:10846926

28. Severo NP, Leite CQ, Capela MV, Simões MJ. Clinical and demographic characteristics of patients hospitalized with tuberculosis in Brasil between 1994 and 2004. J Bras Pneumol. 2007;33(5):565-71. http://dx.doi.org/10.1590/ S1806-37132007000500012 PMid:18026655

29. Paixão LM, Gontijo ED. Profile of notified tuberculosis cases and factors associated with treatment dropout [Article in Portuguese]. Rev Saude Publica. 2007;41(2):205-13. http://dx.doi.org/10.1590/S0034-89102007000200006 PMid:17384794

30. Medeiros D, Sucupira ED, Guedes RM, Costa AJ. Análise da qualidade das informações sobre tuberculose no município de Belford Roxo, Rio de Janeiro, 2006 a 2008. Cad Saude Colet. 2012;20(2):146-52.

\section{About the authors}

Silvana Gomes Nunes Piva

Assistant Professor. University of the State of Bahia, Campus Vll, Senhor do Bonfim, Brazil.

Maria da Conceição Nascimento Costa

Professor of Epidemiology. Collective Health Institute, Federal University of Bahia, Salvador, Brazil.

Florisneide Rodrigues Barreto

Professor of Epidemiology. Collective Health Institute, Federal University of Bahia, Salvador, Brazil.

Susan Martins Pereira

Professor of Epidemiology. Collective Health Institute, Federal University of Bahia, Salvador, Brazil. 